\title{
Snow algae in a Himalayan ice core: new environmental markers for ice-core analyses and their correlation with summer mass balance
}

\author{
Yoshitaka YOSHIMURA, ${ }^{*}$ Shiro KOHSHIMA,${ }^{1}$ Nozomu TAKEUCHI, ${ }^{1 \dagger}$ \\ Katsumoto SEKO, ${ }^{2}$ Koji FUJITA ${ }^{2}$ \\ ${ }^{1}$ Tokyo Institute of Technology, Ookayama 2-12-1-W3-43, Meguro-ku, Tokyo 152-8551, Japan \\ E-mail: ystk@agr.tamagawa.ac.jp \\ ${ }^{2}$ Graduate School of Environmental Studies, Nagoya University, Nagoya 464-8601, Japan
}

\begin{abstract}
Snow algae in a shallow ice core $(6.98 \mathrm{~m}$ long) from Yala glacier in the Langtang region of Nepal were examined for potential use as environmental markers in ice-core analysis. The ice core, taken at 5350 m a.s.l. in 1994, was estimated to contain 11 annual layers from 1984 to 1994 from the profile of algal biomass. Algal biomass in each annual layer was noted to be correlated with air temperature, and the following two environmental indices which were calculated from air temperature and precipitation at Kyangjing (3920 $\mathrm{m}$ a.s.I.), the village nearest to Yala glacier: estimated mean snowcover thickness (MST) and estimated summer mass balance (SMB). Both parameters reflect snow-cover thickness on algal layers, which would be a major determinant of the light available for algal growth on the glacier. Snow algal biomass in the ice core appears to be a good environmental marker for indicating air temperature and accumulation during summer, which is important for understanding the mass balance of summer-accumulation-type glaciers in this region.
\end{abstract}

\section{INTRODUCTION}

Recently microorganisms in snow and ice environments have received increasing attention, particularly those from ice cores obtained in polar regions (Priscu and others, 1998; Willerslev and others, 1999; Christner and others, 2000, 2001, 2003; Sheridan and others, 2003). In these ice cores, very low numbers of microorganisms were reported. Most of the microorganisms were considered to be airborne and it was thought they could not have grown on the glacier, because meltwater essential for microbial activity is extremely limited in these regions. On the other hand, ice cores from low-latitude regions like the Himalaya contain microorganisms such as snow algae which are able to grow on the glacier because snowmelting occurs with the warmer air temperatures (Yoshimura and others, 1997). Yoshimura and others (2000) studied snow algae in an ice core from Yala glacier in the Langtang region of Nepal and, based on pit observation and monitoring of algal growth at the coring site, showed that snow layers with snow algae (algal layers) were formed annually near the surface of the accumulation area by algal growth during the summer (primarily from mid-June to August). They also showed that the algal layers were reliable boundary markers of annual layers useful for ice-core dating in that glacier. Snow algae from ice cores in lowlatitude regions like the Himalaya could be useful for icecore dating because seasonal variations in isotopic and chemical content of the ice cores are often heavily disturbed by meltwater percolation. Yoshimura and others (1997) showed that the biomass and species composition

*Present address: Faculty of Agriculture, Tamagawa University, Tamagawa Gakuen 6-1-1, Machida, Tokyo 194-8610, Japan.

Present address: Research Institute for Humanity and Nature, Takashimacho 335, Kyoto 602-0878, Japan. of snow algae growing on Yala glacier clearly changed with altitude, reflecting changes in environmental conditions. Thus, the biomass and species composition of the snow algae recorded in the ice core are potentially able to provide information on past environmental conditions on the glacier that affected their growth.

In the present study, the same ice core was examined to assess the potential use of the snow algae as new environmental markers. We initially investigated the relationship between algal biomass in each annual layer and environmental conditions during the corresponding year, particularly in regard to nutrient source, water supply and light conditions affecting algal production. To assess the role of nutrient source in algal production during a given year, the relationship between algal biomass and concentration of organic and inorganic particles for an annual layer was investigated because these particles were considered the most likely nutrient source (Yoshimura and others, 1997). The effects of water supply on algal production were clarified by examining the relationship of algal biomass to mean air temperature and precipitation during the growth season at Kyangjing, the village nearest to the glacier. The significance of light conditions was assessed based on the relationship of algal biomass to two indices of snow-cover thickness above an algal habitat, since snow depth would primarily determine the amount of light available. Estimated mean snow-cover thickness (MST) was used as an index of snow thickness. The second index was summer mass balance (SMB). Both of these parameters were determined from air temperature and precipitation during the growth season at Kyangjing. Based on the initial results presented above, biomass was correlated with air temperature, MST and SMB. Our results suggested algal production was mainly affected by the light conditions. Thus algal biomass could prove useful as an environmental marker for examining summer mass balance in Himalayan glaciers. 


\section{METHODS}

\section{Site description}

Yala glacier in the Langtang region of Nepal $\left(28^{\circ} 14-15^{\prime} \mathrm{N}\right.$, $85^{\circ} 36-38^{\prime} \mathrm{E}$; $5100-5700 \mathrm{~m}$ a.s.I.) (Fig. 1a) is a small plateaushaped glacier $\left(2.566 \mathrm{~km}^{2}\right)$. The late-summer equilibrium line of the glacier (10-27 August 1991) has been found to be $5250 \mathrm{~m}$ a.s.l. by stake measurement (Yoshimura and others, 1997), and the ablation area was free of rock debris (Watanabe and others, 1984). Ice coring was conducted at site A (5350 ma.s.l.) located on a flat snowfield (Fig. 1b). Since the coring site was only $100 \mathrm{~m}$ higher than the summer equilibrium line of 1991, it is possible that in warmer years the coring site was in the ablation zone and no accumulation occurred. If such an event occurs, algal biomass should greatly increase. However, it was confirmed by the pit observations that even in the years with highest algal biomass (1991 and 1993) positive accumulation occurred at the coring site (Yoshimura and others, 2000). Thus, the possibility that such an event occurred during the period covered by this core is very low.

\section{Sampling}

A shallow ice core $(6.98 \mathrm{~m}$ long) was taken with a hand auger at site A (Fig. 1b) on 31 July 1994. The core samples were horizontally cut and bagged on site. To avoid contamination, $1 \mathrm{~cm}$ of the core surface was scraped off with a knife which was treated with $70 \%$ ethanol before packaging. Sample vertical length ranged from 3 to $14 \mathrm{~cm}$. Samples were melted at room temperature, transferred to pre-cleaned polyethylene bottles, fixed in $3 \%$ formalin solution and shipped to Japan.

\section{Analysis}

Measurement of algae and particles in the ice core Cell counts and volume determinations were made with a microscope (Nikon Optiphot-2) in bright fields. The melted samples were filtered through Millipore filters (JHWP01300, pore size: $0.45 \mu \mathrm{m}$ ), and $0.5 \%$ Erythrosin (Wako Pure Chemicals Industries, Ltd.) $\left(0.5 \mathrm{~cm}^{3}\right)$ was introduced into the filter holder for staining. The volumes of meltwater used were $0.1-10 \mathrm{~cm}^{3}$. To reduce errors in sampling from the bottles, the bottles were well shaken just before sampling. The filters were rinsed with filter-sterilized distilled water after $20 \mathrm{~min}$ and mounted on glass slides to count the stained algae which were then classified morphologically. All cells were counted twice by the same researcher to reduce counting uncertainties. Morphologically unidentified cells were spherical and divided into six groups according to size $(5-6,7-8,9-10,11-12,13-15,16-20 \mu \mathrm{m}$ in diameter). To check any contamination during the process, blank filters were prepared by filtering the distilled water $\left(10 \mathrm{~cm}^{3}\right)$. Algal cell counts were expressed as cells $\mathrm{cm}^{-3}$, and cell volume $\left(\mu \mathrm{m}^{3}\right)$ was estimated based on size. Total algal biomass was determined by multiplying cell volume $\left(\mu \mathrm{m}^{3}\right)$ by algal density $\left(\right.$ cells $\left.\mathrm{cm}^{-3}\right)$, and algal biomass in each sample was expressed as total algal volume $\left(\mu \mathrm{m}^{3} \mathrm{~cm}^{-3}\right)$. Microparticle $(0.5-20 \mu \mathrm{m}$ in diameter) concentration was determined with a particle counter (Met One L-9000, Transtech Inc.) at the National Institute of Polar Research, Tokyo, Japan.

\section{Estimation of annual algal biomass}

Annual algal biomass was estimated based on the profile of algal biomass (Fig. 2). We assume that major algal peaks a

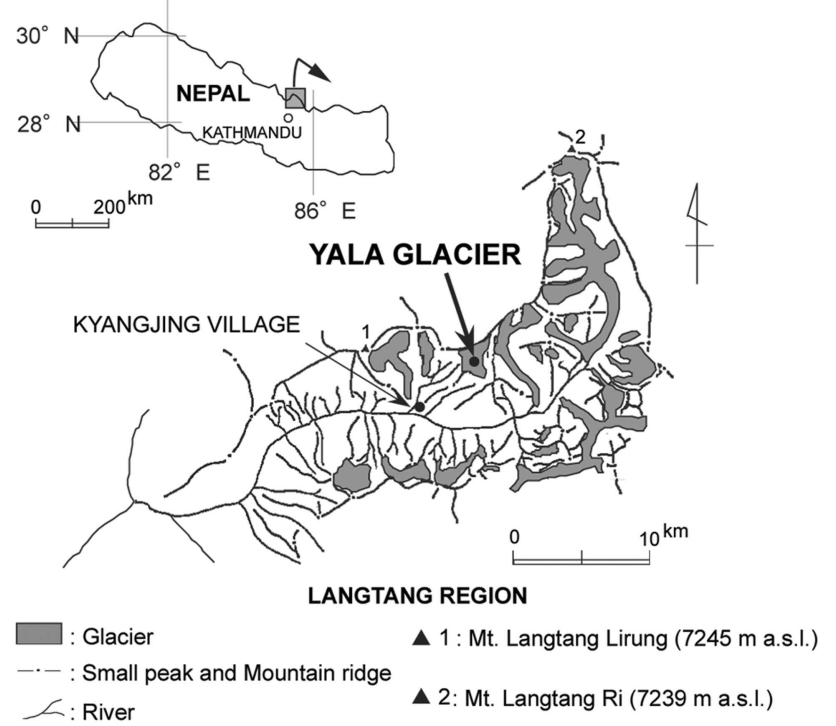

$\mathrm{b}$

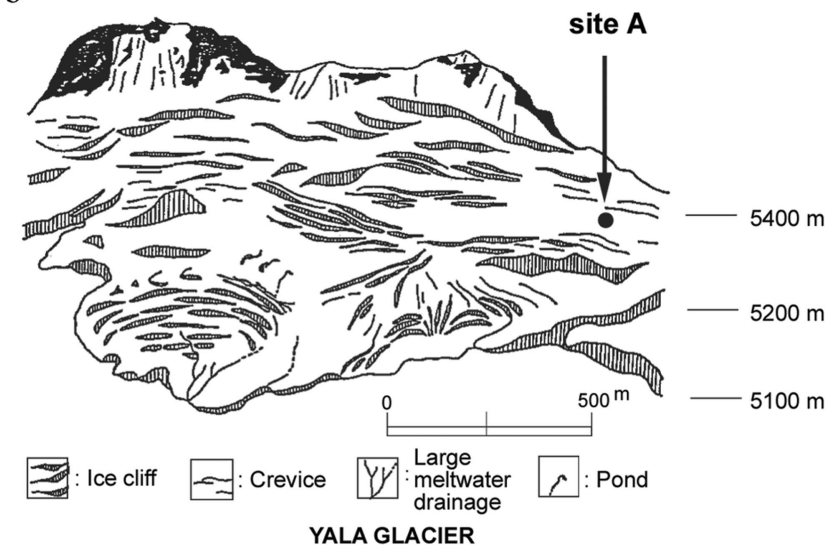

Fig. 1. (a) Site of Yala glacier in the Langtang region, Nepal, and (b) sampling point on this glacier (site A; $5350 \mathrm{~m}$ a.s.l.).

were formed by algal growth on the glacier during midsummer, and that the layers between them with minimum biomass were formed in mid-winter without meltwater which is essential for algal growth (Yoshimura and others, 2000). To estimate the total algal biomass produced during the melt season of each year, we used layers with minimum biomass between major algal peaks (mid-winter layers) as annual layer boundaries, though we used major algal peaks (mid-summer layers) as annual layer boundaries in our previous paper (Yoshimura and others, 2000). Algal biomass of the boundary layer was included in annual biomass of the upper annual layer, in consideration of the downward movement of algal cells with meltwater percolation (Fig. 2). The biomass ratio $\left(\mu \mathrm{m}^{3} \mathrm{~cm}^{-3}\right)$ of each sampled layer present in the annual layer was multiplied by the water equivalent thickness $(\mathrm{cm})$ of the layer, and the values were summed up to calculate annual biomass $\left(\mu \mathrm{m}^{3} \mathrm{~cm}^{-2}\right)$. Snow and ice density used for the calculation was determined by pit observation for the shallower sections of the core $(0-2 \mathrm{~m})$. Below $2 \mathrm{~m}$, it was estimated from the ice-layer rate and firn density at each depth. We estimated the firn density from the stratigraphy and density profile of a $60 \mathrm{~m}$ ice core collected near our coring site (Watanabe and others, 1984) because we could not measure it directly. 


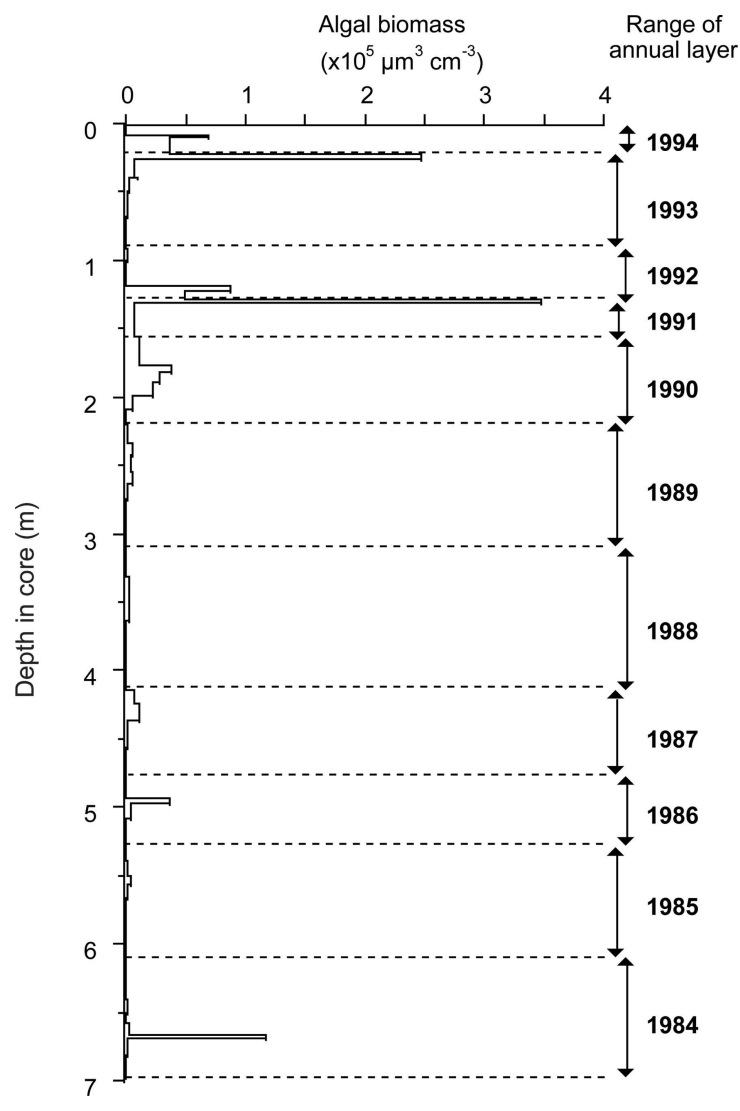

Fig. 2. Vertical profile of snow algal biomass in the ice core taken at site A on Yala glacier in 1994. Dashed line and arrows indicate annual layers for determining annual algal biomass.

\section{Meteorological data analysis}

Air temperature and precipitation at Kyangjing (3920 m a.s.l.; Fig. 1a) were measured by the Nepal Department of Hydrology and Meteorology (DHM), and data were available in annual reports (Nepal Ministry of Water Resources, 1993a, b, c). At the DHM meteorological station in Kyangjing, air temperature was measured continuously with a hygro-thermograph (Thies CLIMA) along with relative humidity. However, daily mean air temperature was calculated based on data obtained every 6 hours (at 0600, 1200, 1800 and $2400 \mathrm{~h}$ ), and read from the graph because only these four time points were available in the annual reports. Daily precipitation was measured using a rain gauge at $0800 \mathrm{~h}$ each day. Data obtained over a period of 7 years (1988-94) were available for reference, though precipitation data for July 1994 and July 1990 were not available from DHM. July 1990 precipitation data collected at Kyangjing by Shiraiwa and others (1992) were available. To compensate for differences in the recording sites and rain gauges used, the data of Shiraiwa were multiplied by the coefficient 0.77 which was derived from values for 62 days when both datasets were available.

\section{Indices of snow-cover thickness}

The estimated MST and the estimated SMB were calculated using daily temperature and precipitation data at Kyangjing from 15 June to 31 August because the main algal growth at site $\mathrm{A}$ was found to occur during this period based on the seasonal observation from 20 May to 3 October in 1996 (Yoshimura and others, 1997). These indices were determined as follows:
1. Daily mass balance $(b)$ at site A on Yala glacier was determined according to the following equations (Ageta and Satow, 1978; Ageta and Kadota, 1992). The original equation for ablation, which yields a semi-monthly value, was modified to provide a daily value by dividing the right side of the equation by 15 .

$$
\begin{array}{rlrl}
b & =c+a, & & \\
c & =P_{\mathrm{g},} & & T_{\mathrm{g}}<-0.6 \\
& =P_{\mathrm{g}}\left(0.85-0.24 T_{\mathrm{g}}\right), & & -0.6 \leq T_{\mathrm{s}} \leq 3.5 \\
a & =0, & & T_{\mathrm{g}}<-3.0 \\
& =-0.01\left(T_{\mathrm{g}}+3.0\right)^{3.2}, & & -3.0 \leq T_{\mathrm{g}} \leq 2.0 \\
T_{\mathrm{g}} & =T_{\mathrm{k}}-0.006(5350-3920), \\
P_{\mathrm{g}} & =1.5 P_{\mathrm{k}}, & &
\end{array}
$$

where $b$ is daily mass balance (cmw.e.), $c$ is daily accumulation ( $\mathrm{cm}$ w.e.), a is daily ablation ( $\mathrm{cm}$ w.e.), $T_{\mathrm{g}}$ is daily mean air temperature at the coring site on the glacier (site $\mathrm{A}$ in Fig. $1 \mathrm{~b})\left({ }^{\circ} \mathrm{C}\right), T_{\mathrm{k}}$ is daily mean air temperature at Kyangjing $\left({ }^{\circ} \mathrm{C}\right), P_{\mathrm{g}}$ is daily precipitation at site $A(\mathrm{~cm})$, and $P_{\mathrm{k}}$ is daily precipitation at Kyangjing $(\mathrm{cm})$. Air temperatures at the glacier were calibrated using a lapse rate of $0.006^{\circ} \mathrm{C} \mathrm{m}^{-1}$. The coefficient 1.5 was based on the data of Shiraiwa and others (1992). They collected the precipitation data in both Kyangjing and Yala glacier during the same period (the monsoon season of 1990).

2. To determine MST, snow-cover thickness on the algal habitat each day was found by summing up the values for daily mass balance for the period from 15 June to the particular day under consideration. On 15 June the thickness was assumed as zero (the algal layer was exposed on the surface) according to the seasonal observation of 1996 (Yoshimura and others, 2000). In cases where the daily snow-cover thickness value was less than zero, it was set at zero. MST was obtained by averaging daily values. Since the above equations were derived for glacier AX010 in Shorong region which is located at about $150 \mathrm{~km}$ southeast of Yala glacier, the determined MST was tested by comparison with observed values at site A between 11 and 26 August 1991; a significant correlation was found between them (Fig. 3; $n=8, r=0.876, P<0.01)$. SMB was derived simply by summing up daily mass-balance values for the period 15 June-31 August. The strong correlation shown in Figure 3 also suggested that the equations used for the calculation of mass balance, the lapse rate and a multiplier of 1.5 $\left(P_{\mathrm{k}}\right)$ were also applicable to this dataset. The relationship between biomass and environmental factors was investigated using regression equations and Pearson's productmoment coefficient of correlation.

\section{RESULTS}

\section{Snow algae found in the ice core}

Seven identifiable algal species and one unidentified alga were observed in the ice-core samples: Trochiscia sp., Chloromonas sp., Mesotaenium berggrenii, Cylindrocystis brebissonii, Ancylonema noldenskioeldii, Raphidonema sp., Oscillatoriacean algae and unidentified coccoid algae. Detailed descriptions of these algae were given in our previous papers (Yoshimura and others, 1997, 2000). 


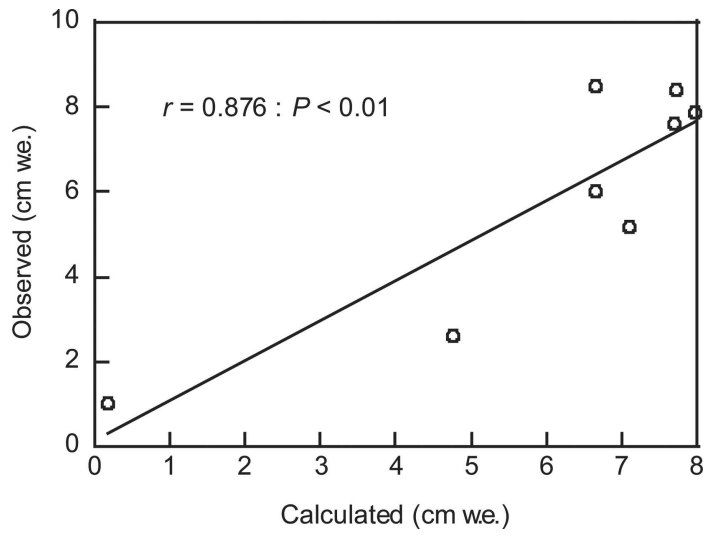

Fig. 3. Correlation between calculated snow-cover thickness and observed values, 11-26 August 1991.

\section{Annual changes in algal biomass and correlation with environmental factors}

Figure 4 shows algal biomass in each annual layer. Algal biomass differs greatly each year, so algal production on the glacier should also differ quite significantly due to considerable variation in environmental conditions from year to year. Figure 5 shows the relationship of algal biomass to environmental factors. The small number of data points shown in Figure $5 \mathrm{~b}-\mathrm{e}$ is due to the limited meterological data collected; air-temperature and precipitation data were available from 1988 to 1994 and 1988 to 1993, respectively. The correlation between algal biomass and microparticle $(0.5-20 \mu \mathrm{m}$ in diameter) concentration for each layer is shown in Figure 5a. These particles may possibly have served as the source of nutrition each year for the algae, but no significant correlation between these parameters could be found and, accordingly, annual algal production would not necessarily depend solely on nutrient source. Figure $5 \mathrm{~b}$ shows the relationship of annual algal biomass to air temperature at Kyangjing (mean value from 15 June to 31 August). Algal biomass in the ice core was well correlated with estimated air temperature at the coring site $(n=7, r=0.773, P<0.05)$, suggesting annual algal production on the glacier might be affected by environmental factors related to air temperature, such as the amount of meltwater available to the algae. Correlation with precipitation is presented in Figure $5 \mathrm{c}$ for Kyangjing (total value from 15 June to 31 August). The correlation can be seen to be weak and negative and is not significant $(n=6, r=-0.726, P>0.1)$. Figure $5 \mathrm{~d}$ and e, respectively, show the relationship of annual algal biomass to MST and SMB. The correlation with MST $(n=6, r=-0.975$, $P<0.01)$ and SMB $(n=6, r=-0.968, P<0.01)$ is quite strong, suggesting that algal production is affected by light intensity.

\section{DISCUSSION}

Environmental conditions that affect algal biomass in the ice core

Algal biomass in each annual layer was found to be uncorrelated with the concentration of microparticles in an annual layer (Fig. 5a). Since aqueous nutrients were

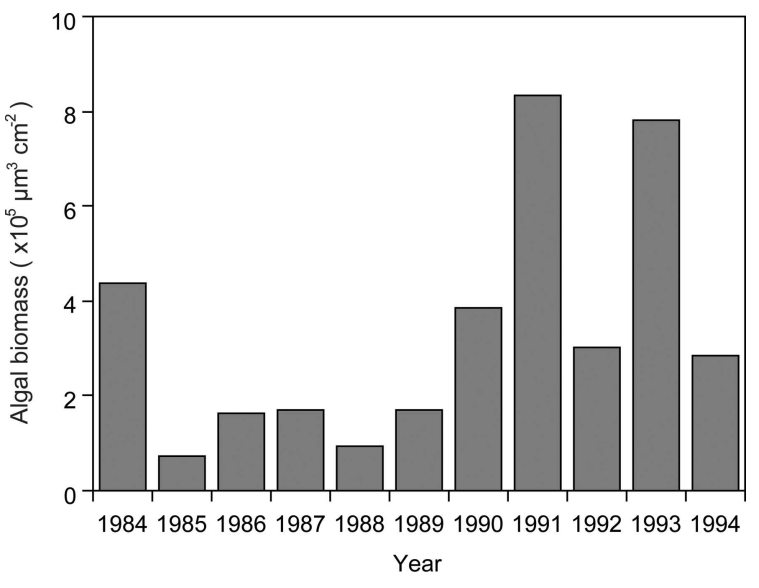

Fig. 4. Annual change in algal biomass, 1984-94. Annual biomass $\left(\mu \mathrm{m}^{3} \mathrm{~cm}^{-2}\right)$ was computed by multiplying sample biomass density $\left(\mu \mathrm{m}^{3} \mathrm{~cm}^{-3}\right)$ for the annual layer by water equivalent thickness $(\mathrm{cm})$.

extremely limited on the glacier and algae were found mainly in snow and ice with many organic and inorganic wind-blown particles, these particles were estimated to be more important nutrient sources than aqueous nutrients (Yoshimura and others, 1997). The absence of any correlation between the microparticle concentration and biomass would indicate that the amount of particles available as a nutrient source is not the major determining factor in annual algal production. In contrast, a good correlation was found to exist between annual algal biomass and air temperature. Annual algal production appears to depend significantly on the amount of meltwater since the quantity of meltwater and the period of availability to the algae increases with air temperature.

A strong negative correlation of algal biomass with MST and $\mathrm{SMB}$ would indicate algal biomass to be primarily determined by snow cover, which largely controls the amount of light available to algae. The snow-cover thickness should greatly affect the biomass because the light intensity decreases significantly (exponentially) in the snow (Richardson and Salisbury, 1977). The snow-cover thickness is determined by air temperature and precipitation, so these meteorological conditions have a significant role in algal production. But should biomass be determined by light alone, it would show negative correlation with MST and SMB exponentially. The linear negative correlation between the two snow-cover indices and biomass is possibly an indication of the action of certain other environmental factors such as the amount and availability of meltwater and/or nutrient elution from the particles determined by air temperature and precipitation. The algal biomass on the glacier has been shown to rapidly decrease with altitude (Yoshimura and others, 1997), and biomass was greater at lower altitude, higher temperature and when there was less snow cover. The algal biomass would thus appear largely to be determined by air temperature and snow-cover thickness.

\section{Snow algae as useful environmental markers for ice-core analysis}

Based on the results of this study, the annual change in biomass of snow algae should qualify as a new environmental marker in ice-core studies of Himalayan glaciers. Snow algal biomass appears to be an environmental marker 

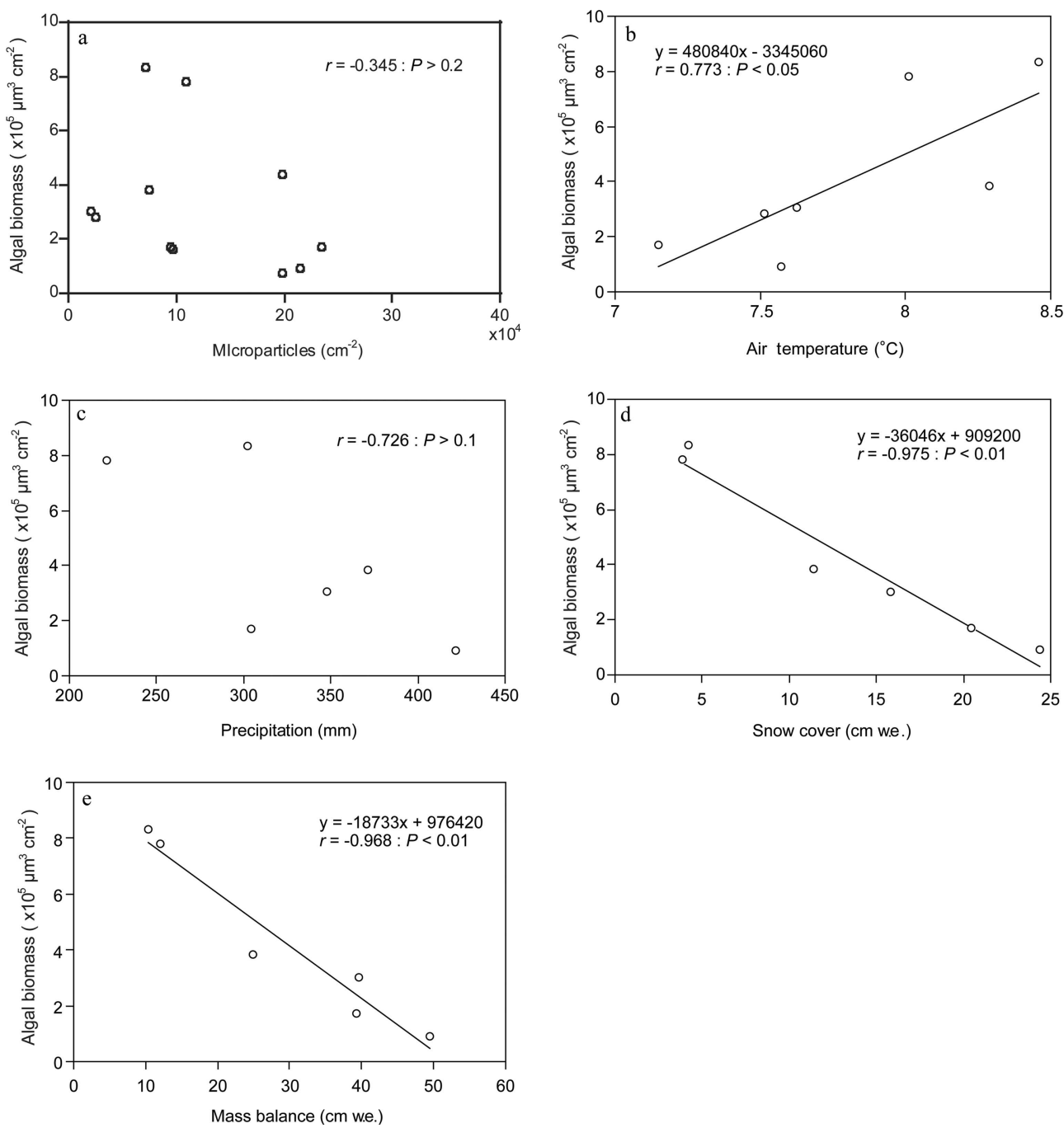

Fig. 5. Correlation of annual biomass with environmental factors during algal growth period (15 June-31 August): (a) microparticles (0.5$20 \mu \mathrm{m}$ in diameter); (b) air temperature at Kyangjing (3920 ma.s.l.); (c) precipitation at Kyangjing; (d) MST on algal layer at site A (5350 m a.s.I.); and (e) SMB at site A. Growth period was determined based on seasonal observation in 1996. MST and SMB derived based on daily temperature and precipitation at Kyangjing.

of air temperature and mass balance during the algal growth season and might provide information essential for clarifying summer-accumulation-type (one-season-dependent type) glaciers of this region, where major accumulation and ablation occur at the same time in the summer (Ageta and Satow, 1978). However, we should note that our results are based on a very limited number of data points and assumptions that could be potential sources of error. For example, in calculating MST and SMB, we assumed that the main algal growth season was 15 June-31 August based on the seasonal observation in 1996 neglecting possible interannual variability.

Our results also show the potential of snow algae as useful environmental markers for ice-core analysis in lower-latitude and lower-altitude glaciers where signals of stable isotopes and chemical ions are often destroyed by heavy meltwater percolation. However, before snow algae can be used as reliable environmental markers in ice-core analysis, more studies are needed. For example, we should study the ecology of snow algae more precisely in glaciers of various regions, especially their relationship with environmental conditions. Studies on deeper ice cores, spatial variability of algal biomass on the glacier, and post-depositional processes of algal cells in the glacial strata are needed to improve the reliability of this method. To analyze snow algae in deeper ice cores, development of new techniques to identity and quantify the microorganisms more rapidly and precisely is also needed.

\section{CONCLUSIONS}

Algal biomass in annual layers in a Himalayan ice core was found to be significantly correlated with air temperature and the two indices of the snow-cover thickness during the algal growth season (mid-June to August), but not with microparticles, which are a probable nutrient source for the algae. Algal production on Yala glacier possibly depends on snowcover thickness which determines the intensity of light available for algal growth, as well as on the amount and period of availability of snow meltwater. Algal biomass could be a new environmental marker reflecting summer mass balance and thus could be useful for obtaining information to understand summer-accumulation-type glaciers of this region. However, more studies are needed before snow algae can be used as reliable environmental markers for ice-core analysis. 


\section{ACKNOWLEDGEMENTS}

We express sincere appreciation to the Department of Hydrology and Meteorology, Ministry of Water Resources, Nepal, for valuable support. The Sherpa people and Langtang village are gratefully acknowledged for kindly assisting the fieldwork. Thanks are also due to T. Shiraiwa of Hokkaido University and K. Ueno of University of Shiga Prefecture for providing meteorological data in Kyangjing. We thank anonymous reviewers for thoughtful comments which improved the manuscript. This study was supported by the Ministry of Education, Science, Sports and Culture of Japan under grant Nos. 13480154, 06041051, 09490018, 16310004, R12 and A10.

\section{REFERENCES}

Ageta, Y. and T. Kadota. 1992. Predictions of changes of glacier mass balance in the Nepal Himalaya and Tibetan Plateau: a case study of air temperature increase for three glaciers. Ann. Glaciol., 16, 89-94.

Ageta, Y. and K. Satow. 1978. Study of the mass balance of small glaciers in Khumbu Himal during the summer monsoon season. Seppyo, 40, Special Issue, 4-11.

Christner, B.C., E. Mosley-Thompson, L.G. Thompson and V. Zagorodnov. 2000. Recovery and identification of viable bacteria immured in glacial ice. Icarus 144, 479-485.

Christner, B.C., E. Mosley-Thompson, L.G. Thompson and J.N. Reeve. 2001. Isolation of bacteria and 16S rDNAs from Lake Vostok accretion ice. Environ. Microbiol., 3(9), 570-579.

Christner, B.C., E. Mosley-Thompson, L.G. Thompson and J.N. Reeve. 2003. Bacterial recovery from ancient glacial ice. Environ. Microbiol., 5, 433-436.

Nepal Ministry of Water Resources. 1993a. Snow and glacier hydrology year book 1987-1992. Kathmandu, Ministry of Water Resources. Department of Hydrology and Meteorology.
Nepal Ministry of Water Resources. 1993b. Snow and glacier hydrology year book 1987-1992 (Supplement III). Kathmandu, Ministry of Water Resources. Department of Hydrology and Meteorology.

Nepal Ministry of Water Resources. 1993c. Snow and glacier hydrology year book 1987-1992 (Supplement IV). Kathmandu, Ministry of Water Resources. Department of Hydrology and Meteorology.

Priscu, J.C. and 9 others. 1998. Perennial Antarctic lake ice: an oasis for life in a polar desert. Science, 280(5372), 2095-2098.

Richardson, S.G. and F.B. Salisbury. 1977. Plant response to the light penetrating snow. Ecology, 58, 1152-1158.

Sheridan, P.P., V.I. Miteva and J.E. Brenchley. 2003. Phylogenetic analysis of anaerobic material psychophilic enrichment cultures obtained from a Greenland glacier ice core. Appl. Environ. Microb., 69, 2153-2160.

Shiraiwa, T., K. Ueno and T. Yamada. 1992. Distribution of mass input on glaciers in the Langtang Valley, Nepal Himalayas. Bull. Glacier Res., 10, 21-30.

Watanabe, O., S. Takenaka, H. lida, K. Kamiyama, K.B. Thapa and D.D. Mulmi. 1984. First results from Himalayan glacier boring project in 1981-1982. Part I. Stratigraphic analysis of full-depth cores from Glacier Boring Project 1981-1982 in Nepal Himalaya. In Higuchi, K., ed. Glacial studies in Langtang Valley: a report of the Glacier Boring Project 1981-1982 in the Nepal Himalayas. Nagoya, Japanese Society of Snow and Ice Office. Data Centre for Glacier Research, 7-23.

Willerslev, E., A.J. Hansen, B. Christensen, J.P. Steffensen and P. Arctander. 1999. Diversity of Holocene life forms in fossil glacier ice. Proc. Natl. Acad. Sci. USA, 96(14), 8017-8021.

Yoshimura, Y., S. Kohshima and S. Ohtani. 1997. A community of snow algae on a Himalayan glacier: change of algal biomass and community structure with altitude. Arct. Alp. Res., 29(1), 126-137.

Yoshimura, Y., S. Kohshima, N. Takeuchi, K. Seko and K. Fujita. 2000. Himalayan ice-core dating with snow algae. J. Glaciol., 46(153), 335-340. 